\title{
Expert Meeting Report: Advanced Envelope Research for Factory Built Housing
}

E. Levy, M. Mullens, E. Tompos, B. Kessler, and P. Rath ARIES Collaborative

April 2012 


\section{NOTICE}

This report was prepared as an account of work sponsored by an agency of the United States government. Neither the United States government nor any agency thereof, nor any of their employees, subcontractors, or affiliated partners makes any warranty, express or implied, or assumes any legal liability or responsibility for the accuracy, completeness, or usefulness of any information, apparatus, product, or process disclosed, or represents that its use would not infringe privately owned rights. Reference herein to any specific commercial product, process, or service by trade name, trademark, manufacturer, or otherwise does not necessarily constitute or imply its endorsement, recommendation, or favoring by the United States government or any agency thereof. The views and opinions of authors expressed herein do not necessarily state or reflect those of the United States government or any agency thereof.

Available electronically at http://www.osti.gov/bridge

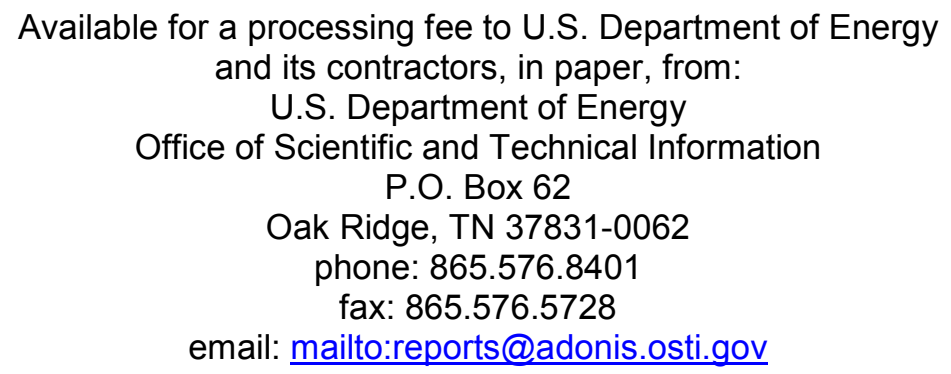

Available for sale to the public, in paper, from:

U.S. Department of Commerce

National Technical Information Service

5285 Port Royal Road

Springfield, VA 22161

phone: 800.553 .6847

fax: 703.605.6900

email: orders@ntis.fedworld.gov

online ordering: http://www.ntis.gov/ordering.htm

\footnotetext{
Printed on paper containing at least $50 \%$ wastepaper, including $20 \%$ postconsumer waste
} 


\title{
Expert Meeting Report: Advanced Envelope Research for Factory Built Housing
}

\author{
Prepared for: \\ Building America \\ Building Technologies Program \\ Office of Energy Efficiency and Renewable Energy \\ U.S. Department of Energy
}

Prepared by:

E. Levy, M. Mullens, E. Tompos, B. Kessler and P. Rath

ARIES Collaborative

The Levy Partnership, Inc., 1776 Broadway, Suite 2205

New York, NY 10019

NREL Technical Monitor: Michael Gestwick

Prepared under Subcontract No. KNDJ-0-40347-00

April 2012 
[This page left blank] 


\section{Contents}

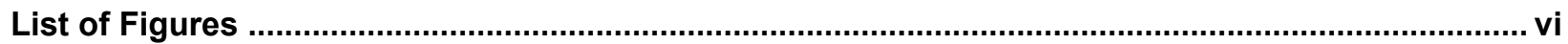

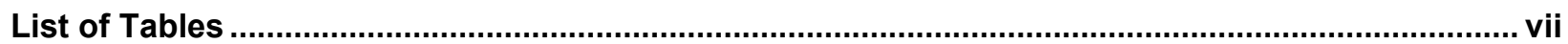

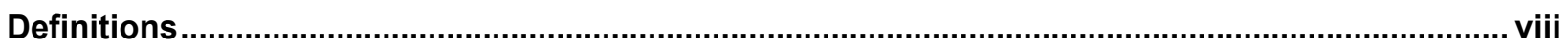

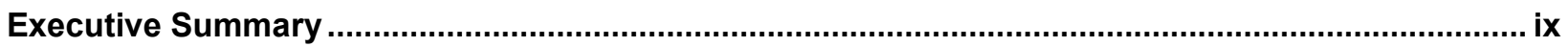

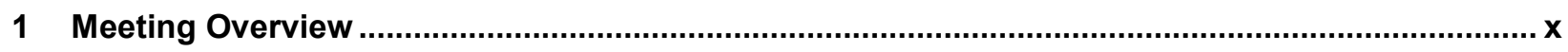

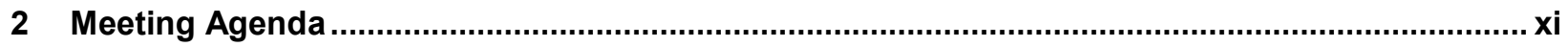

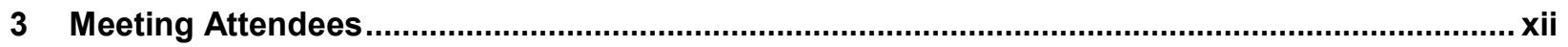

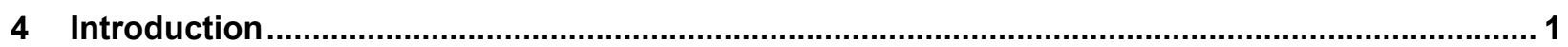

5 Overview of the Advanced Envelope Research Concepts...................................................... 1

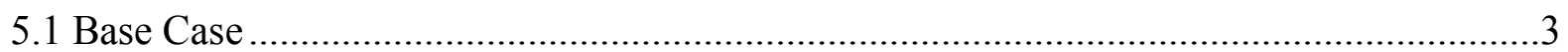

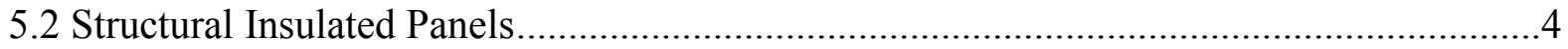

5.3 Stud walls with Structural Insulative Sheathing .........................................................6

5.4 Flash and Batt wall construction.............................................................................. 7

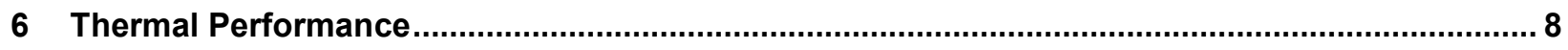

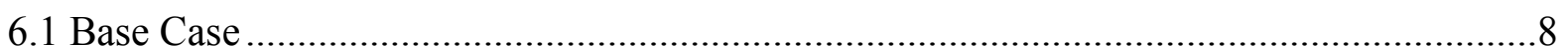

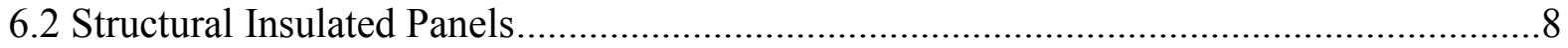

6.3 Stud walls with Structural Insulative Sheathing ....................................................... 9

6.4 Flash and Batt wall construction.......................................................................... 9

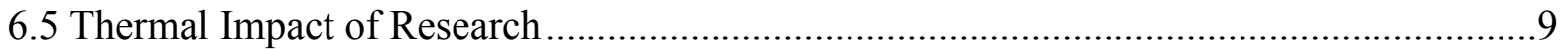

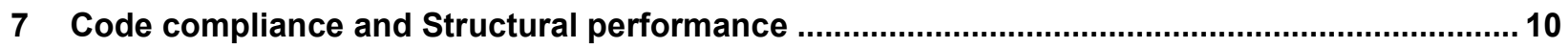

7.1 Compliance with the HUD Code ...................................................................................... 10

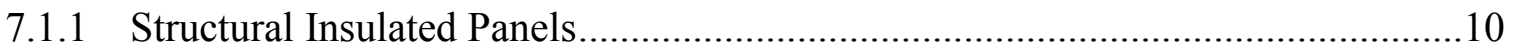

7.1.2 Stud walls with Structural Insulative Sheathing ..........................................11

7.1.3 Flash and Batt wall construction................................................................... 11

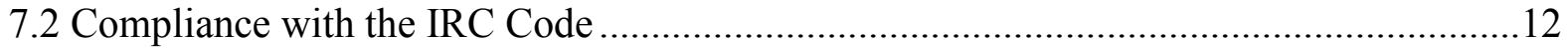

7.2.1 Structural Insulated Panels....................................................................... 12

7.2.2 Stud walls with Structural Insulative Sheathing ............................................. 12

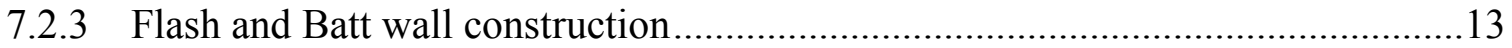

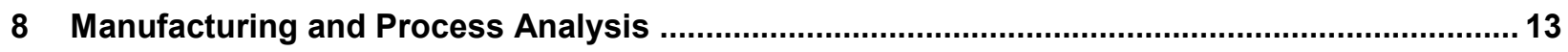

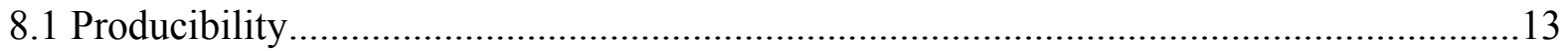

8.1.1 Structural Insulated Panels...................................................................... 14

8.1.2 Stud walls with Structural Insulative Sheathing ............................................. 15

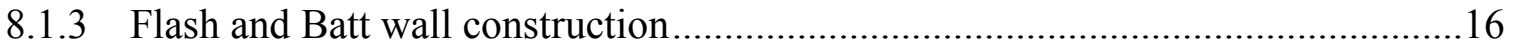

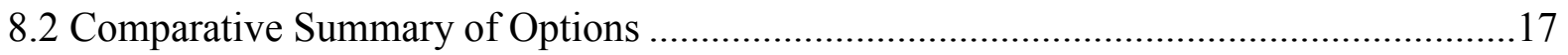

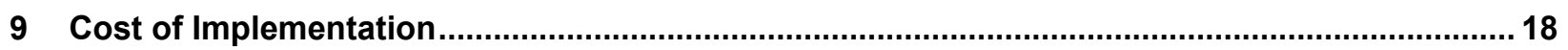

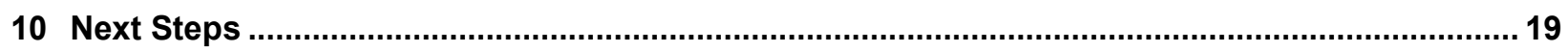

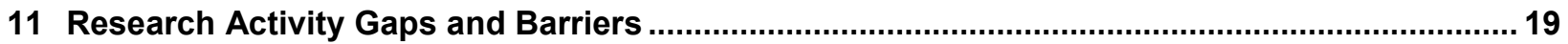




\section{List of Figures}

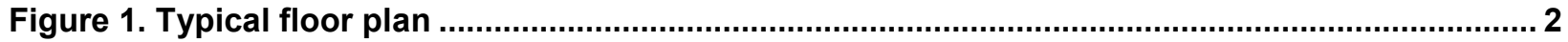

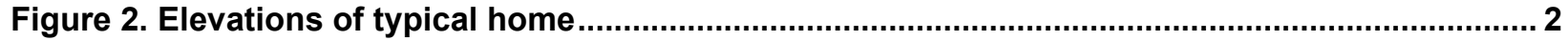

Figure 3. Thermal Zone maps: IECC (2009) and HUD MHCSS (1994) ….......................................... 3

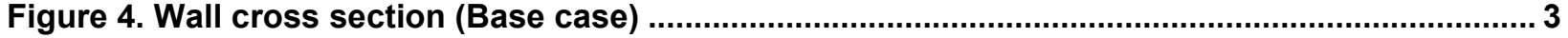

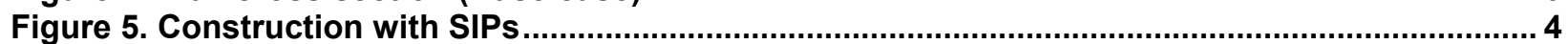

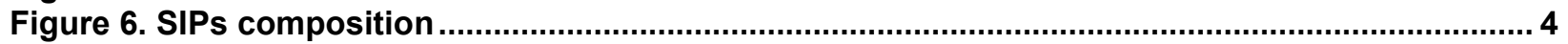

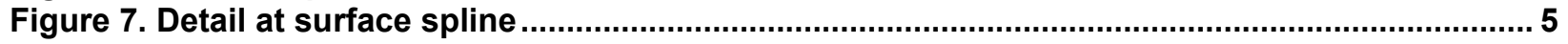

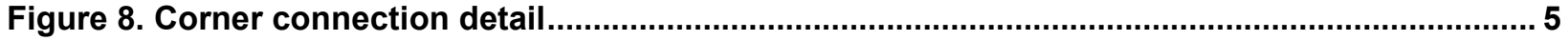

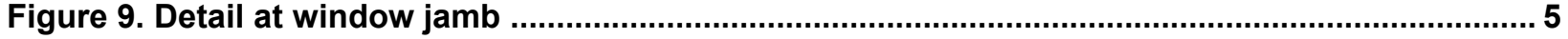

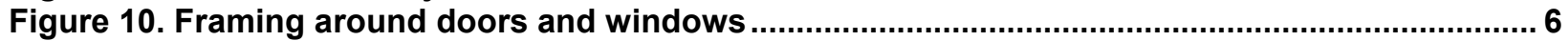

Figure 11. Stud walls with structural insulative sheathing: Plan view ............................................ 6

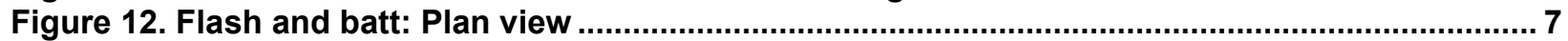

Figure 13. Plant-level value stream mapping for the Norris Plant ................................................ 14

Figure 14. Panel layout for front sidewall of 'model' home ............................................................. 15

Unless otherwise noted, all figures were created by the ARIES team. 


\section{List of Tables}

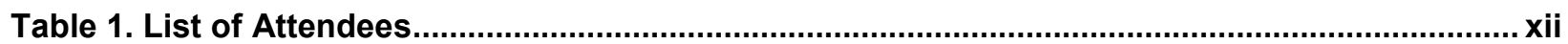

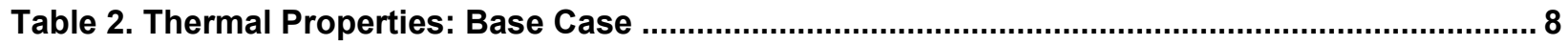

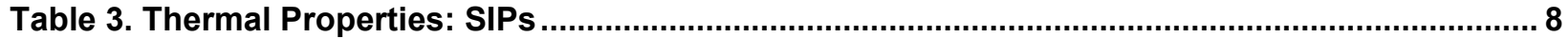

Table 4. Thermal Properties: Stud Walls with Structural Insulative Sheathing ................................. 9

Table 5. Thermal Properties: Flash and Batt Wall Construction ......................................................... 9

Table 6. Whole House Performance of Options.......................................................................... 10

Table 7. Translating $U_{0}$-Value Impact into Cost Savings ............................................................... 10

Table 8. Comparison of Marginal Labor Between Options ................................................................. 17

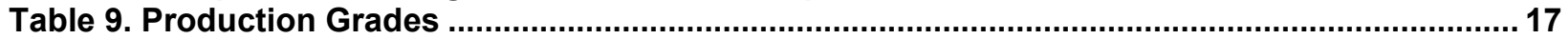

Table 10. Comparison of Fixed Costs of Options..................................................................... 18

Table 11. Marginal Costs by Production Volume (\$/sq. ft. of net wall area) .................................... 18

Unless otherwise noted, all tables were created by the ARIES team. 


\section{Definitions}

IECC

SIP

HUD

IRC

SPF
International Energy Conservation Code

Structural insulated panel

U.S. Department of Housing and Urban Development

International Residential Code

Spray polyurethane foam 


\section{Executive Summary}

The Advanced Envelope Research effort will provide factory homebuilders with urgentlyneeded, cost effective methods for meeting emerging energy code requirements. For manufactured homes, the thermal requirements, last updated by statute in 1994, will move up to the more stringent IECC 2009 (or 2012) levels in 2012. This places added urgency on identifying innovative, high-performance solutions that the industry can implement in the short term.

This work is a multi-year development effort, divided into three phases. Phase 1, completed in July 2011, identified and provided a preliminary assessment of three optional methods for building high performance wall systems. Phase 2 is focused on the development of viable product designs, manufacturing strategies, addressing code and structural issues, and, cost analysis of the selected options. Phase 3, scheduled to begin in early 2012, will consist of full scale implementation, testing and evaluation.

The approach to the project and scope is shaped by the following three overarching considerations:

1. One of the major challenges in the development process is creating product designs and fabrication methods that minimize total cost while maximizing product performance. The product designers and process designers each start with a set of goals but must engage in a development process that arrives at a common, integrated and optimized solution. The process of bringing diverse goals to a common development process in which several disciplines simultaneously re-engineer the building product and process, and work to integrate and synergize their solutions is often referred to as concurrent engineering.

2. This research effort is being driven by the unique requirements of factory homebuilding. Researchers aim to seek synergies among building materials, automated production equipment and information technology. Then, guided by the principles of lean production, researchers will explore how the whole system can be reinvented to dramatically improve quality, energy efficiency, safety, cost effectiveness, productivity and design flexibility.

3. In all homes, but particularly in factory built housing, ${ }^{1}$ performance of systems, subsystems and components are dependent on other systems within the structure; and improving performance in one area has collateral impacts elsewhere. For example, changes in the envelope subsystem intended to improve energy efficiency may affect the production process and may alter the structural characteristics of the home. Optimization of any single part of the home therefore depends on balancing considerations elsewhere. The team employs a systems approach designed to find combinations of changes that together improve overall performance when gauged relative to an objective baseline.

\footnotetext{
${ }^{1}$ Concurrent engineering benefits factory built housing more than other less industrialized forms of housing for several reasons including the fact that the economics of the plant construction process are far more dependent upon speed, coordination of trades and dimensional precision. In addition, quality control and coordination of the trades is more easily accomplished in the factory than at the building site.
} 


\section{Meeting Overview}

\section{Title}

"Advanced Envelope Research for Factory Built Housing, Phase 2: Design and Development"

\section{Research question}

Phase 1 of the research identified viable alternatives for building high performance wall systems in factory built homes, a key part of the solution for improving overall energy performance.

The research questions addressed by the Phase 2 Expert meeting were:

- Which of these technologies best address the needs of complying with more stringent codes and standards while holding the line on affordability? and,

- What further refinements need to be made in the concepts through prototype construction, testing, process simulation and evaluation?

\section{Goals of the meeting}

The goals of the meeting were:

- Provide a comprehensive solution to the use of three previously selected advanced alternatives for factory-built wall construction

- Critically assess each option focusing on major issues relating to viability, and

- Evaluate and decide which options (if any) have commercial potential, and, what additional steps are required to reach this potential.

\section{Location}

The meeting was held in Phoenix, Arizona on October 2, 2011. Web access was provided for experts unable to attend in person.

\section{Organizers}

The meeting was organized by the ARIES Collaborative Building America research team led by The Levy Partnership, Inc. 


\section{Meeting Agenda}

Introduction

$1: 00 \mathrm{pm}$

Welcome and self-introductions

Project goals, background and status

Goals for the meeting

Meeting structure

Technology Presentations

Overview of Advanced Envelope Concepts

$1: 15 \mathrm{pm}$

- Concept

- Strengths and weaknesses of the technology

- Design, including materials and construction details

- Proprietary materials and alternates

Thermal performance................................................................................... 2:00 pm

Structural performance and code compliance ....................................... 2:30 pm

Break ............................................................................. 2:45 pm

Manufacturing process....................................................................................... 3:00 pm

Cost of implementation........................................................................... 4:00 pm

Technologies covered in each section of the Technology Presentations

- Base case design

- Structural insulated panels (SIPs)

- Stud walls with structural insulative sheathing

- Flash and batt wall construction

Comparison and prioritization of technologies $4: 30 \mathrm{pm}$

Research and technical hurdles $5: 30 \mathrm{pm}$

Next steps $5: 45 \mathrm{pm}$

Conclude 6:00 pm 


\section{Meeting Attendees}

Table 1. List of Attendees

\begin{tabular}{|ll|}
\hline Steering Committee & \\
\hline Michael Wade, Cavalier Homes, Committee Chair & mwade@cavhomesinc.com \\
\hline Mark Ezzo, Clayton Homes & mark.ezzo@clayton.net \\
\hline Bert Kessler, Palm Harbor Homes & bkessler@palmharbor.com \\
\hline David Kurth, All American Group & dkurth@allamericangroupinc.com \\
\hline Manuel Santana, CAVCO/Fleetwood/Palm Harbor Homes & manuels@cavco.com \\
\hline Bill Stamer, Champion Enterprises & bstamer@championhomes.com \\
\hline Lois Starkey, MHI & Lstarkey@mfghome.org \\
\hline Advisors & \\
\hline Teri Davis, CertainTeed & Teri.L.Davis@saint-gobain.com \\
\hline Dean DeWildt, DOW & DPDewildt@dow.com \\
\hline Michael Fay, Johns Manville & michael.fay@jm.com \\
\hline James Lambach, Bayer MaterialScience & james.lambach@bayer.com \\
\hline Craig Marden, Owens Corning & Craig.Marden@owenscorning.com \\
\hline Brian Oman, BASF & brian.oman@basf.com \\
\hline Mike Tobin, AFM Corp. & mtobin@afmcorporation.com \\
\hline Guests & \\
\hline Jim Dunn, Eagle River Homes, Inc. & jdunn@eagleriverhomes.net \\
\hline Jayar Daily, American Homestar Corp. & frdaily@hstr.com \\
\hline Michael Gestwick, NREL/DOE & michael.gestwick@nrel.gov \\
\hline ARIES Team Technical Staff & \\
\hline Emanuel Levy, The Levy Partnership, Inc & elevy@research-alliance.org \\
\hline Michael Mullens, The Levy Partnership, Inc & mullensm@mail.ucf.edu \\
\hline Pournamasi Rath, The Levy Partnership, Inc & prath@research-alliance.org \\
\hline Eric Tompos, NTA & etompos@ntainc.com \\
\hline & \\
\hline
\end{tabular}




\section{Introduction}

\section{Background}

The Expert Meeting was held to discuss and evaluate the research effort conducted during Phase 2. In this phase of the Advanced Envelope Research, detailed designs were developed for three high thermal performance envelope technologies: SIPs for walls; stud walls with structural insulative sheathing; and, flash and batt wall construction. These technologies were selected in Phase 1 for further study by the project committee consisting of leading factory building companies. Selection was based on a preliminary assessment of thermal performance, manufacturability, cost and other issues. The objective of this phase was to develop and refine the design for each technology so that performance is optimized for factory-built housing and significant issues related to concept viability could be identified. This information provided the basis for the industry committee to compare and contrast the options and decide which have commercial potential.

\section{Justification of need}

Most factory built homes are constructed under the nationally pre-emptive manufactured housing standards (referred to as the HUD standards). The standards were last updated in 1994. The US Department of Energy is currently working on changes to these standards that are anticipated to be enacted in 2012. The technical basis for the new requirements will be either the 2009 or 2012 version of the IECC. The industry currently has no attractive options for meeting the anticipated thermal provisions of these standards. In response, this research effort will provide innovative and cost-effective solutions for achieving the higher envelope efficiency performance.

\section{Relevance to Building America Goals}

This project will provide factory homebuilders with urgently-needed, cost effective methods for meeting emerging energy code requirements. Incorporation of proposed wall technologies will be a major step towards meeting the 50\% target improvement in home energy use.

\section{Overview of the Advanced Envelope Research Concepts}

\section{Context}

Developing alternative designs and evaluating their costs and benefits requires establishing a context, a set of study parameters that shape the solutions presented. These parameters helped the team understand typical conditions for the building companies that are likely users of the research products.

The study parameters consisted of the following:

- Typical home features: 56' x 28' multi-section unit, 8' ceiling height, $11 \%$ window area and 1,101 sq. $\mathrm{ft}$. net wall area

- Home layout: A representative home design was selected with a foot print measuring 56' x 28' (see below). 


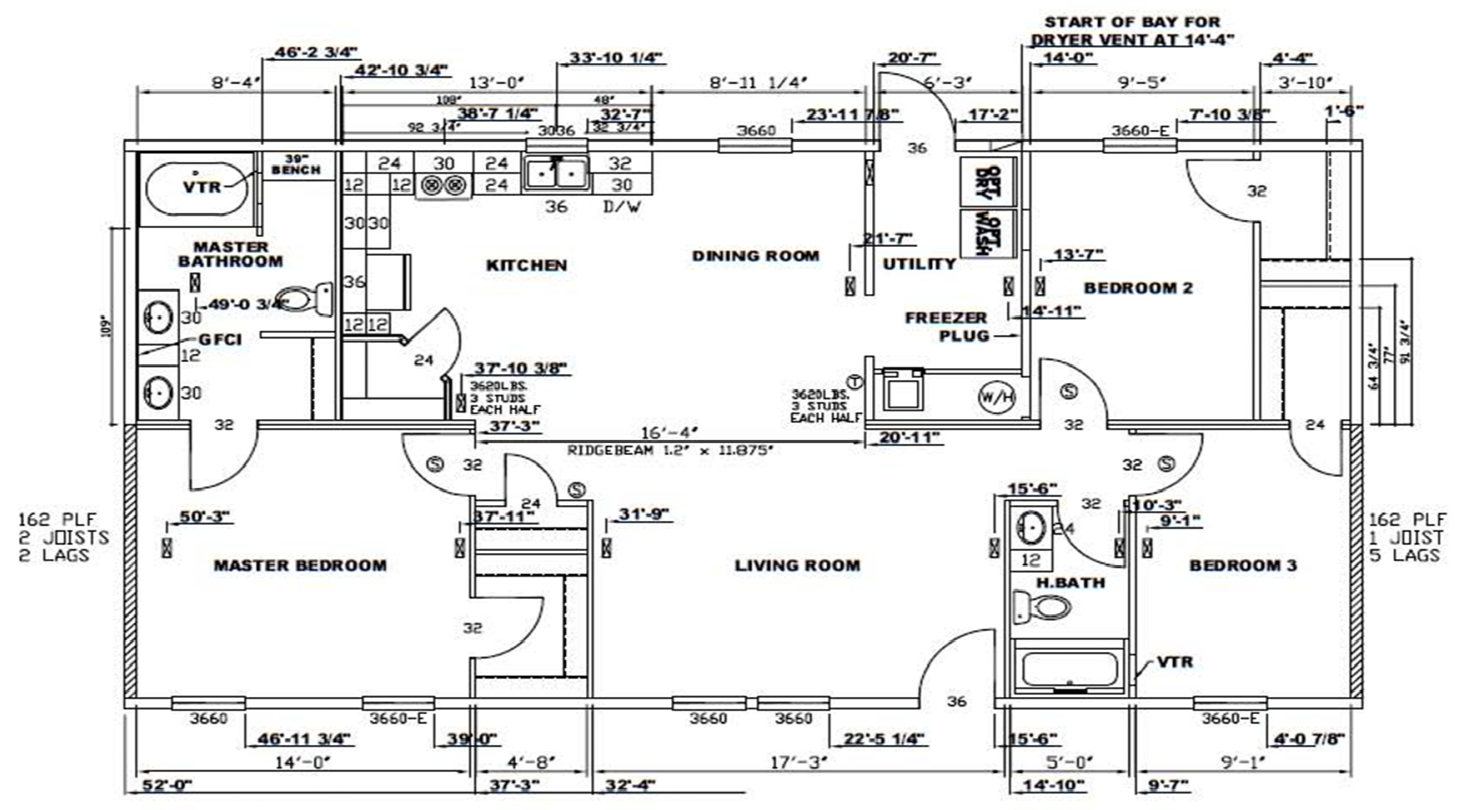

Figure 1. Typical floor plan

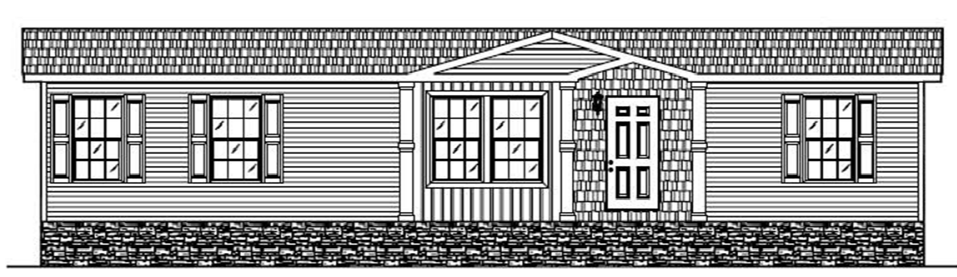

FRONT ELEVATION

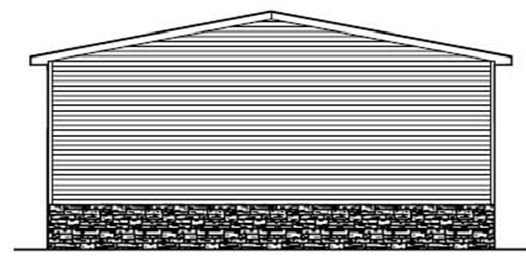

LEFT SIDE ELEVATION

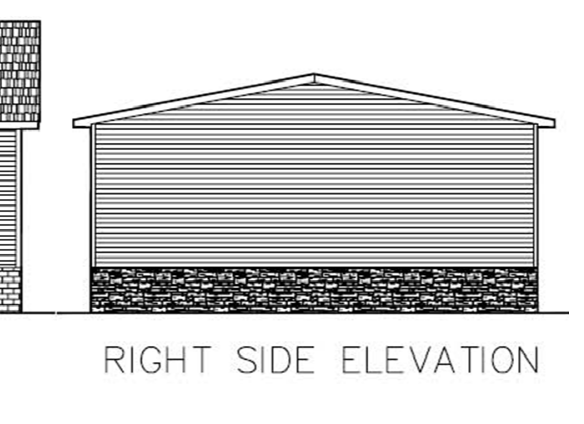

RIGHT SIDE ELEVATION

\section{REAR ELEVATION}

Figure 2. Elevations of typical home

- Manufacturing facility: The typical end user is a plant serving cold, northern climates of the US. A single manufacturing plant was selected to typify plants in this area. CMH/Norris Homes Facility \#927, Bean Station, TN. Bean Station is considered typical in many respects, including projected plant capacity of 1,000 homes $(2,000$ floors $)$ per year. 
- Climate: homes located in IECC 2009 climate zones 5 and higher

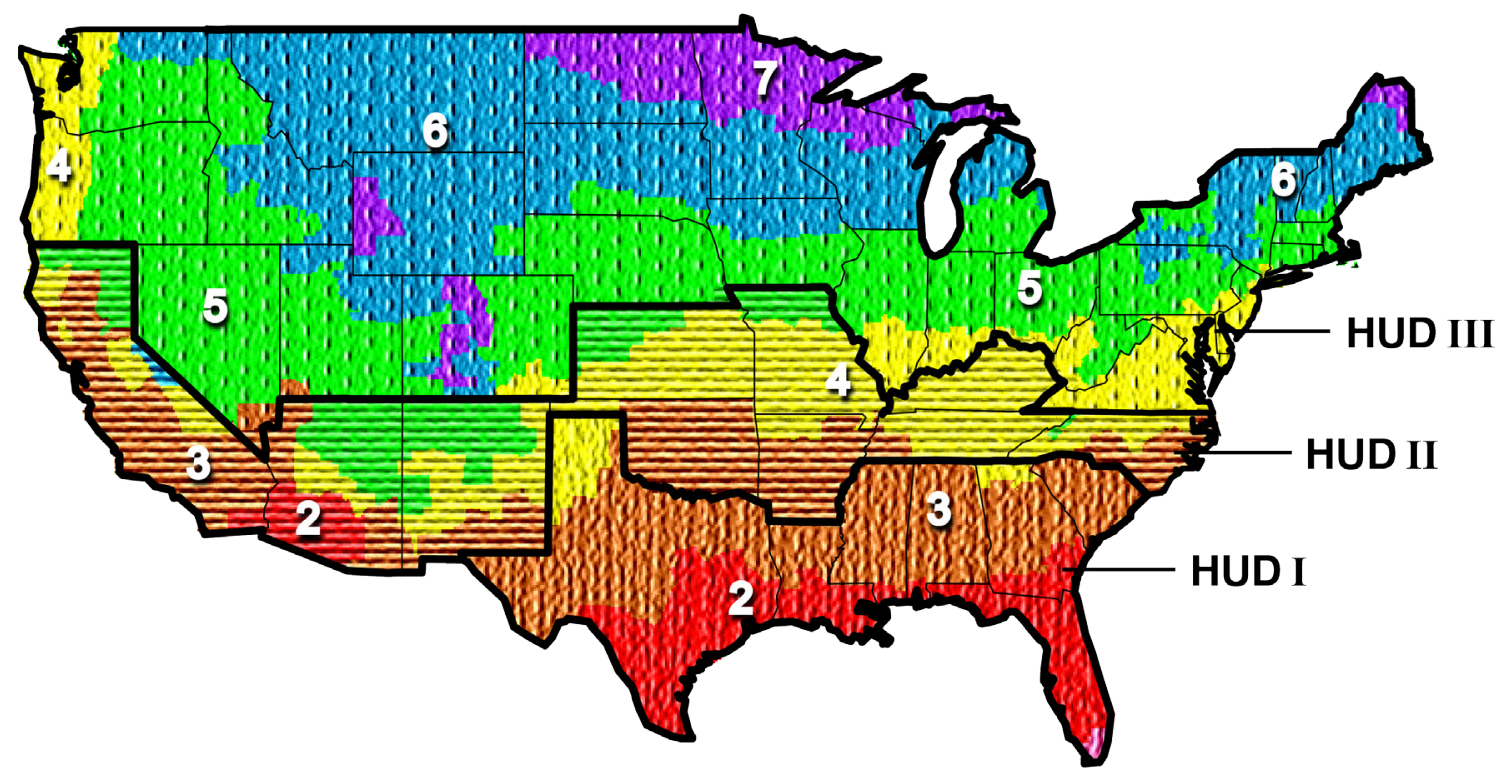

Figure 3. Thermal Zone maps: IECC (2009/2012) and HUD MHCSS (1994)

Source: Figure R301.1 Climate Zones. Excerpted from the 2012 International Energy Conservation Code, Copyright 2011. Washington D.C.: International Code Council. Reproduced with permission. All rights reserved. www.ICCSAFE.org

The Expert Meeting presented findings related to thermal performance, code compliance issues, factory manufacturability and cost for three advanced walls designs:

- Structural insulated panels (SIPs)

- Stud walls with structural insulative sheathing

- Flash and batt wall construction.

The presentation included a "base case" design, a reference point for measuring the value of the options. The base case is a wall design that would likely be used by industry in the absence of an advanced solution to meet stringent energy standards.

\subsection{Base Case}

\section{Wall construction}

The base case wall is composed of $2 \times 6$ studs spaced 16" apart with 7/16" exterior OSB sheathing and 1/2" gypsum board on the inside. Insulation in cavity is 5-1/2" of high density fiberglass batts (R-21).

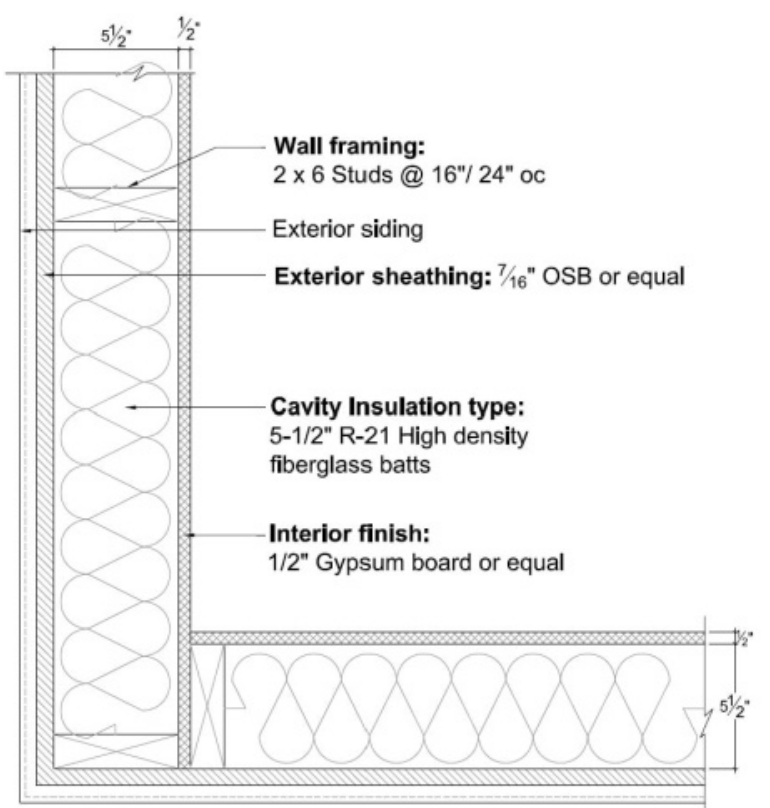

Figure 4. Wall cross section (base case) 


\subsection{Structural Insulated Panels (SIPs)}

\section{Concept}

A sandwich panel comprised of expanded polystyrene insulation core between sheathing layers. The insulation core is glued to the sheathing creating a composite panel of high strength and rigidity.

\section{Strengths}

- High structural strength

- Minimal thermal bridging

- Superior structural stability

- Extremely air-tight

- Speed and ease of construction

- Fewer parts and joints reduce opportunity for errors in wall assembly

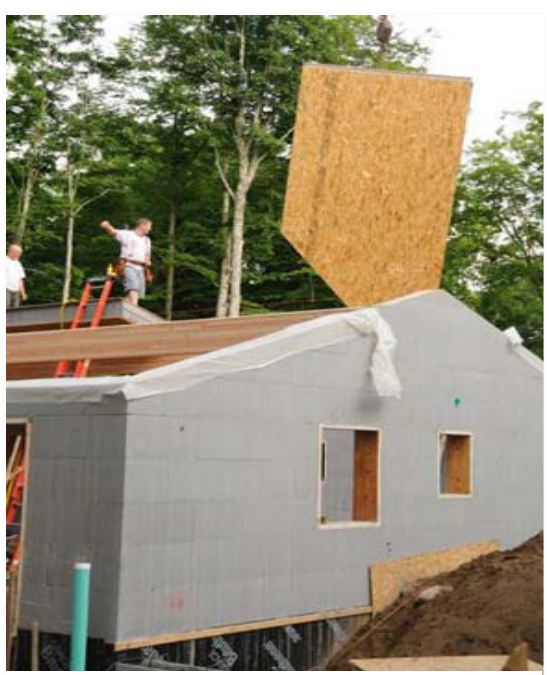

Figure 5. Construction with SIPs

- Monolithic structure reduces service calls related to gypsum board cracks.

\section{Weaknesses}

- The very tight construction tolerance of SIPs must be reflected in the fabrication of interfacing components to prevent rework and delay

- Air-tightness requires controlled fresh-air ventilation for healthy indoor air performance

- Panels are heavier than the other alternatives

- Redundancy of having OSB sheathing as the interior face of the composite panel

- In-house production of SIPs critical to controlling costs and attaining assembly advantages. Requires significant capital investment and floor space availability.

- Customized SIPs must be consistently produced to specification minimizing flow disruptions. Disruptions to SIP production can slow home production

- Relatively high cost.

\section{Design}

- Core insulation: Expanded polystyrene (EPS) blocks 5-1/2" thick

- Sheathing: $7 / 16^{\prime \prime}$ oriented strand board (24' x 8') on both sides

- Panel framing: Surface spline with $1 \mathrm{x}$ or $2 \mathrm{x}$ top and bottom plates

- Interior finish: Gypsum board or equal.

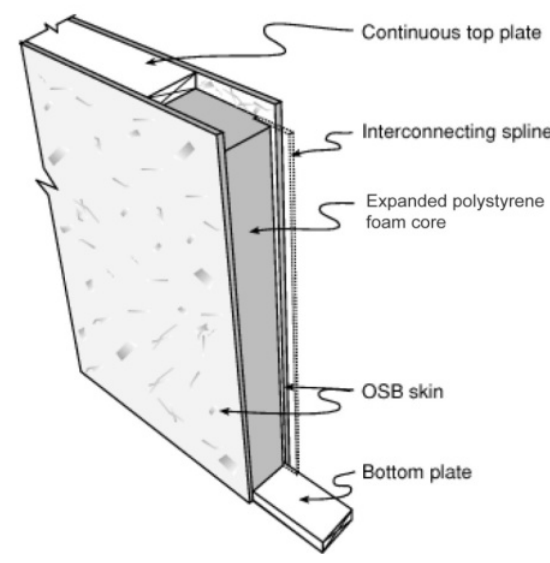

Figure 6. SIPs composition 


\section{Construction Details}

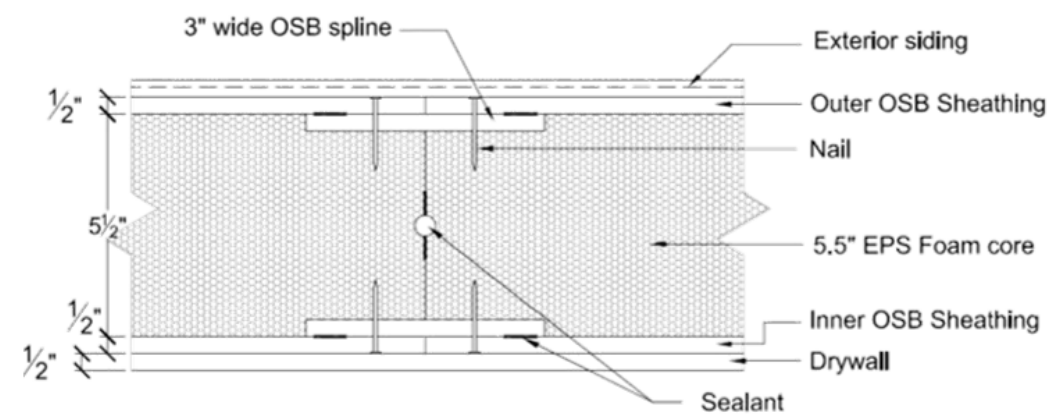

Figure 7. Detail at surface spline

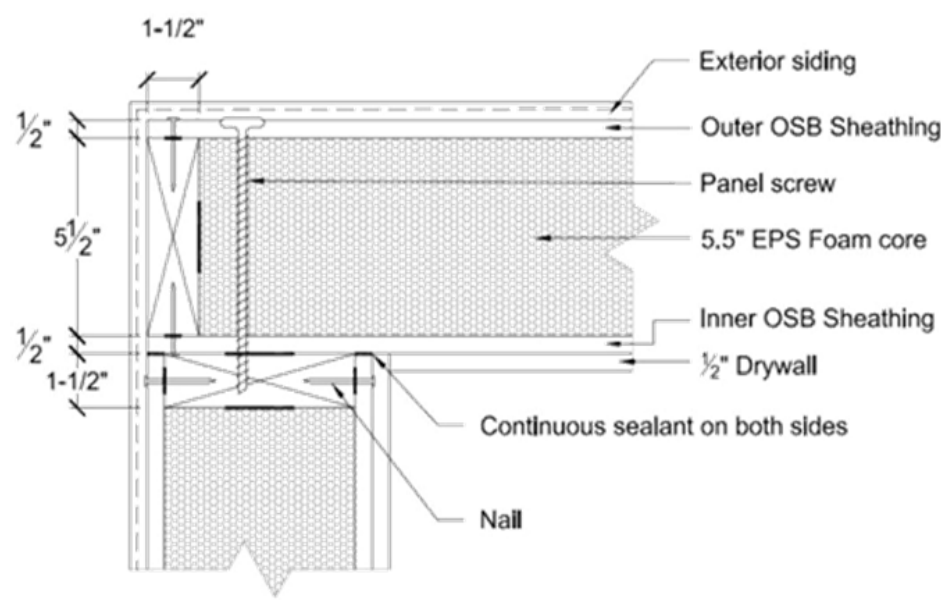

Figure 8. Corner connection detail

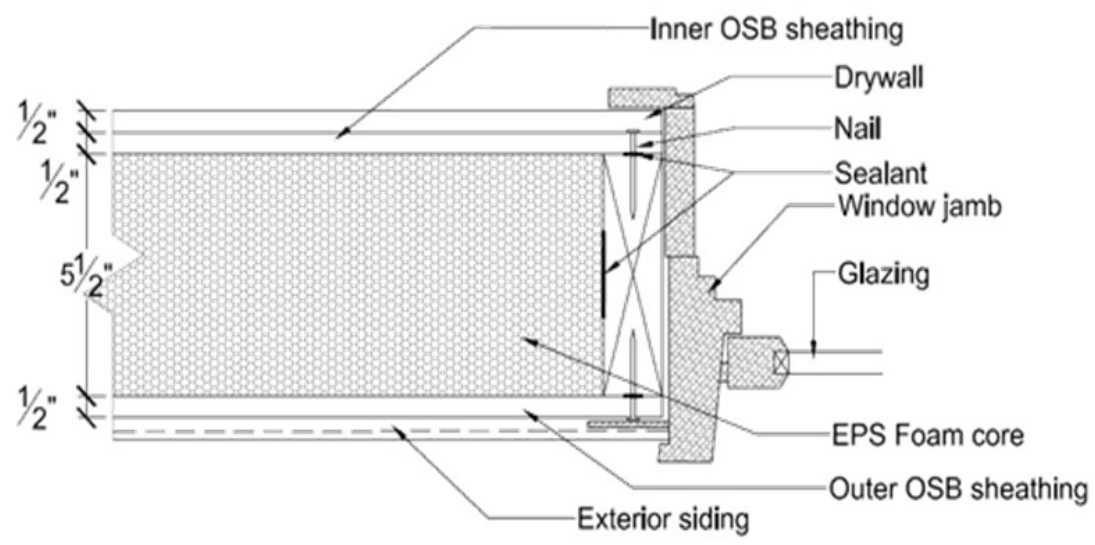

Figure 9. Detail at window jamb 


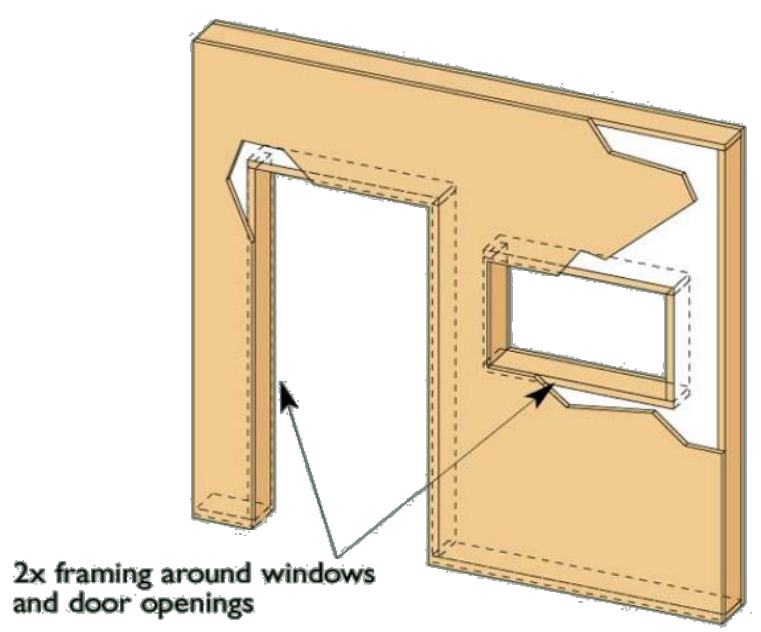

Figure 10. Framing around doors and windows

\subsection{Stud Walls with Structural Insulative Sheathing}

\section{Concept}

This wall design combines wood stud construction with a nearly continuous semi-structural foam board to achieve improved superior thermal performance and strength.

\section{Strengths}

- Combines some of the structural advantages of SIPs with improved thermal performance at a lower cost per R-value

- Thermally somewhat more efficient

- Reduces lumber use resulting in lighter wall construction.

\section{Weaknesses}

- Material cost of "structural" insulative sheathing can be higher

- Potential for moisture condensation needs further investigation

- Lighter 2" x 3" framing may result in increased service calls for gypsum board cracking.

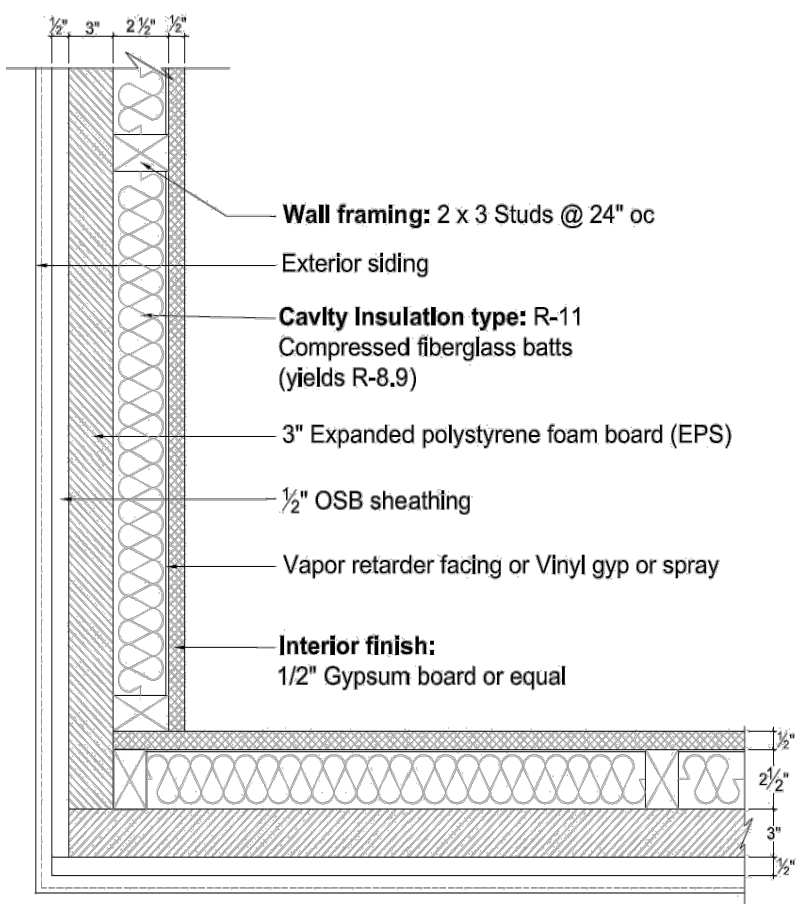

Figure 11. Stud walls with structural insulative sheathing: Plan view 


\subsection{Flash and Batt Wall Construction}

\section{Concept}

Hybrid application of two insulation materials:

- Relatively high R-value spray foam filling part of the wall cavity, with

- Standard fiberglass batt insulation.

\section{Strengths}

- Higher R-value with standard frame construction. Achieves higher overall wall U-value than standard frame construction with fiberglass batts of equal depth.

- Low air infiltration rate. Sealing the joints between framing and interior sheathing reduces air leakage through the walls.

- Production impact is modest and can be contained to wall build area

- Maximizes the benefits of expensive spray foam insulation while minimizing the total cost through the use of less expensive fiberglass batts

- $\quad$ Spray foam acts as a vapor barrier

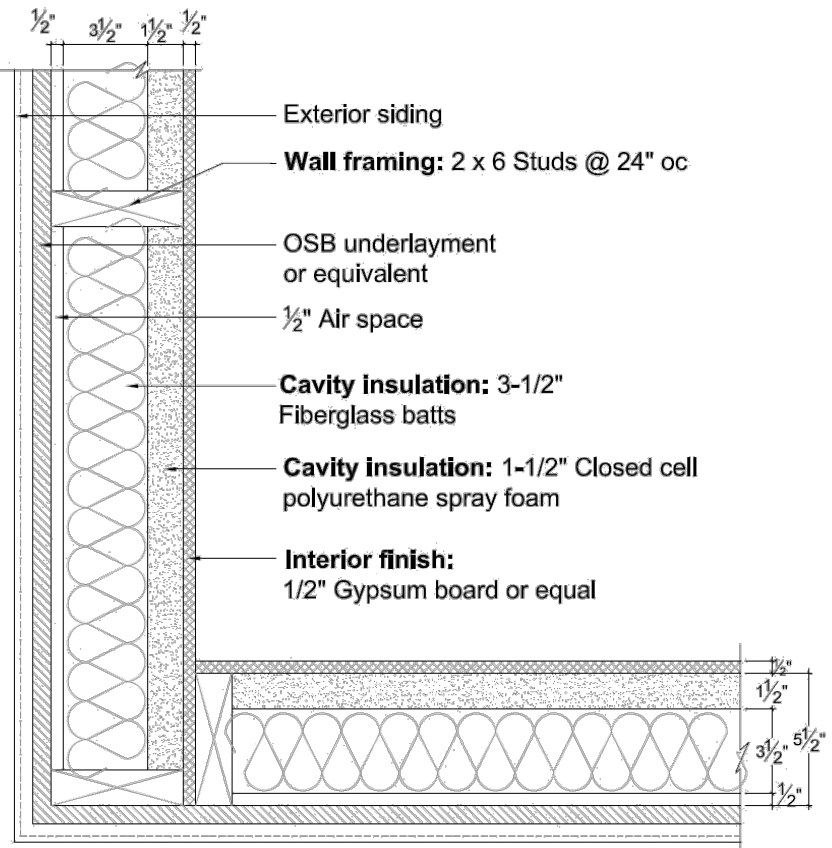

Figure 12 Flash and batt: Plan view (minimum 1" thick)

- Potential to reduce service calls due to gypsum board cracks

- Possible opportunity to reduce factory labor cost and improve finish quality by eliminating gypsum board screws.

\section{Weaknesses}

- Factory flow disrupted by problems with spray system

- $\quad$ SPF is a hazardous material during spray process requiring protective equipment and 10' buffer to other workers

- SPF sprayer must be elevated either on top of framing table or, on ladder or catwalk

- Tank temperature must be maintained

- Relatively higher cost per R-value

- Equipment maintenance adds to overall costs. 


\section{Thermal Performance}

The designs were developed with the goal of meeting the prescriptive requirements of the IECC 2009 standards, either through the prescriptive or whole component performance as defined below for climate zones 5 and 6 :

- Prescriptive: $\mathbf{R - 2 0}$ or R-13+5 (Wall insulation R-value)

or,

- Whole wall performance: 0.057 (Wall U-factor)

Using one dimensional heat flow analysis with calculated framing fractions, the wall R-value and the whole wall U-value were calculated for all options and compared with the base case.

\subsection{Base Case}

Thermal properties of the base case are tabulated below.

Table 2. Thermal Properties: Base Case

\begin{tabular}{|l|c|}
\hline Component & Base case \\
\hline Wall framing & $2 \times 6 @ 16^{\prime \prime}$ o.c. \\
\hline Framing fraction & $14.98 \%$ \\
\hline Cavity thickness & $5-1 / 2^{\prime \prime}$ \\
\hline FG batt thickness & $5-1 / 2^{\prime \prime}$ \\
\hline FG batt R-value & R-21 (High density) \\
\hline Total wall R-value & $\mathbf{R - 2 1}\left(\mathbf{R - 2 0 ^ { 2 }}\right)$ \\
\hline $\mathbf{U}_{\text {wall-value }}$ & $\mathbf{0 . 0 5 2}(\mathbf{0 . 0 5 7})$ \\
\hline $\mathbf{U}_{\mathbf{0}}$-value & $\mathbf{0 . 0 3 7}$ \\
\hline
\end{tabular}

\subsection{Structural Insulated Panels}

Thermal properties of the SIP wall are summarized in Table 3.

Table 3. Thermal Properties: SIPs

\begin{tabular}{l|c}
\hline Component & Property \\
\hline Wall specs & $6 "$ thick panel with combination of surface and framing splines \\
\hline Framing fraction & $6.05 \%$ \\
\hline OSB sheathing thickness & $1 / 2 "$ \\
\hline EPS foam core thickness & $5-1 / 2 "$, R-22 \\
\hline
\end{tabular}

\footnotetext{
${ }^{2}$ IECC 2009 code requirement for climate zone 5.

${ }^{3}$ Assumes $\mathrm{U}_{\text {ceiling }}=0.030$ and $\mathrm{U}_{\text {floor }}=0.033$, as per IECC 2009 code for CZ 5
} 


\begin{tabular}{|c|c|}
\hline Component & Property \\
\hline Total wall R-value & $R-22\left(R-20^{2}\right)$ \\
\hline$U_{\text {wall }}$-value & $0.043\left(0.057^{3}\right)$ \\
\hline
\end{tabular}

\subsection{Stud Walls with Structural Insulative Sheathing}

Thermal properties of stud walls with structural insulative sheathing are summarized below.

Table 4. Thermal Properties: Stud Walls with Structural Insulative Sheathing

\begin{tabular}{l|c}
\hline Component & Property \\
\hline Wall framing & $2 \times 3 @ 24 "$ o.c. \\
\hline Framing fraction & $6.05 \%$ \\
\hline Cavity thickness & $2-1 / 2^{\prime \prime}$ \\
\hline Fiberglass batts & $2-1 / 2 " / R-8.9(\mathrm{R}-11$ compressed) \\
\hline Expanded polystyrene (EPS) & $3 "(\mathrm{R}-12)$ \\
\hline OSB sheathing thickness & $1 / 2 "$ \\
\hline Total wall R-value & $\mathbf{R - 2 0 . 9}\left(\mathbf{R}-\mathbf{2 0}{ }^{2}\right)$ \\
\hline $\mathbf{U}_{\text {wall }}^{- \text {-value }}$ & $\mathbf{0 . 0 4 3}\left(\mathbf{0 . 0 5 7 ^ { 3 }}\right)$ \\
\hline
\end{tabular}

\subsection{Flash and Batt Wall Construction}

Thermal properties of the flash and batt wall construction are summarized in Table 5.

Table 5. Thermal Properties: Flash and Batt Wall Construction

\begin{tabular}{l|c}
\hline Component & Property \\
\hline Wall framing & $2 \times 6 @ 24 "$ o.c. \\
\hline Framing fraction & $12.15 \%$ \\
\hline Cavity thickness & $5-1 / 2 "$ \\
\hline Fiberglass batts & $3-1 / 2^{\prime \prime}(\mathrm{R}-11)$ \\
\hline Spray foam (CC Polyurethane) thickness & $1-1 / 2^{\prime \prime}(\mathrm{R}-10)$ \\
\hline Total wall R-value & $\mathbf{R - 2 1}\left(\mathbf{R}-\mathbf{2 0}{ }^{2}\right)$ \\
\hline $\mathbf{U}_{\text {wall }}^{- \text {-value }}$ & $\mathbf{0 . 0 5 0}\left(\mathbf{0 . 0 5 7 ^ { 3 }}\right)$ \\
\hline
\end{tabular}

\subsection{Thermal Impact of Research}

The whole house performance of the options was analyzed and the impact translated into cost savings per square foot. Results are shown on Tables 6 and 7. 
Table 6. Whole House Performance of Options

\begin{tabular}{l|c|c}
\hline Research options & $\mathbf{U}_{\text {wall }}$-value & $\Delta \mathbf{U}_{\mathbf{0}}$-value $^{3}$ \\
\hline SIPs & 0.043 & -0.003 \\
\hline Stud walls with structural insulative sheathing & 0.043 & -0.003 \\
\hline Flash and batt wall construction & 0.050 & -0.002 \\
\hline Base case & 0.052 & -0.002 \\
\hline
\end{tabular}

Table 7. Translating $U_{0}-$ Value Impact into Cost Savings

\begin{tabular}{|c|c|c|}
\hline Research options & Example impact on other components & $\begin{array}{l}\text { Savings } \\
\text { (\$/sq. ft.) }\end{array}$ \\
\hline $\begin{array}{l}\text { SIPs and } \\
\text { Structural insulative sheathing } \\
\left(\mathrm{U}_{0} \text {-value }=0.043\right)\end{array}$ & $\begin{array}{c}\text { Replace R-38 blown cellulose } \\
(\mathrm{U}-\mathrm{value}=0.029) \text { with } \\
\text { R-33 blown cellulose }(\mathrm{U}-\mathrm{value}=0.032)\end{array}$ & $\$ 0.16$ \\
\hline $\begin{array}{l}\text { Flash and batt } \\
\left(\mathrm{U}_{\mathrm{o}} \text {-value }=0.050\right)\end{array}$ & Same as base case & ---- \\
\hline
\end{tabular}

\section{Code Compliance and Structural Performance}

This section summarizes the basic and supplemental tests required of the three proposed construction strategies to comply with the HUD code (for manufactured homes) and the IRC code (for the modular building industry).

\subsection{Compliance with the HUD Code}

\subsubsection{Structural Insulated Panels}

\section{Basic HUD Code Compliance Requirements:}

Assumption: Wind Zone 1, 5/16" gypsum thermal barrier in interior (24 CFR 3280.207(a)(1)) Information needs: Installation/use instructions (required from product manufacturer), engineering calculations applying the test data to the specific structure and design of SIP-specific connections (required from home manufacturer)

- ASTM E-84-flame spread and smoke-developed of 75 and 450 or less, respectively (24 CFR 3280.207(b)) (Cost \$800)

- ASTM E-96-for use as a vapor retarder, water vapor transmission characteristics (24 CFR 3280.504(b)(1)) must be documented showing a perm less than 1.0. (Cost $\$ 1,200)$

- CFR Title 16, Part 460-documentation of thermal performance (R-value) (Cost \$700)

- ASTM E-72 - Test data establishing axial, transverse, and racking strength (24 CFR 3280.402) (Cost $\$ 10,000)$ 


\section{Supplemental HUD Code Performance Characteristics:}

- HUD Header/Combined Load Testing - door and window openings will require conventional lumber framing unless test data is provided to substantiate SIP header/jamb strength without reinforcement (24 CFR 3280.401) (Cost \$10,000)

- HUD Connection testing - where connections cannot be designed using the NDS, testing is required (24 CFR 3280.401) (Cost \$2,000)

\subsubsection{Stud walls with Structural Insulative Sheathing}

\section{Basic HUD Code Compliance Requirements:}

Assumption: Wind Zone 1, 5/16" gypsum thermal barrier in interior (24 CFR 3280.207(a)(1))

Information needs: Installation/use instructions (required from product manufacturer)

- ASTM E-84-flame spread and smoke-developed of 75 and 450 or less, respectively (24 CFR 3280.207(b)) (Cost \$800)

- CFR Title 16, Part 460-documentation of thermal performance (R-value) (Cost \$700)

\section{Supplemental HUD Code Performance Characteristics:}

- HUD Combined Load Test - if increased transverse wall stiffness/strength requires test data (24 CFR 3280.401). Depending on stiffness of continuous foam testing may validate use of $2 \times 3$ exterior wall framing in Wind Zone I. (Cost \$5500)

- ASTM E-72 - if racking strength is required test data required (24 CFR 3280.401) (Cost $\$ 2400)$

\subsubsection{Flash and Batt wall construction}

\section{Basic HUD Code Compliance Requirements:}

Assumption: Wind Zone 1, 5/16" gypsum thermal barrier in interior (24 CFR 3280.207(a)(1))

Information needs: Installation/use instructions (required from product manufacturer)

- ASTM E-84 test-flame spread and smoke-developed of 75 and 450 or less, respectively (24 CFR 3280.207(b)) (Cost \$800)

- CFR Title 16, Part 460 - documentation of thermal performance (R-value) (Cost $\$ 700$ for new products)

\section{Supplemental HUD Code Performance Characteristics:}

- ASTM E-96 (dry-cup method) — where SPF used as a vapor retarder (24 CFR $3280.504(\mathrm{~b})(1)$ ) documentation of water vapor transmission characteristics (dry-cup method) less than 1 perm. (Cost $\$ 1,200$ )

- ASTM E-72 - if SPF is to provide extra structural strength in Wind Zones 2 or 3, to demonstrate increased transverse wall stiffness (reduced deflection) (24 CFR 3280.402); (Cost \$2,400)

- Racking test - for specific designs or conditions where the SPF is to provide racking resistance (24 CFR 3280.401) (Cost \$2,400) 


\subsection{Compliance with the IRC Code}

\subsubsection{Structural Insulated Panels}

\section{Basic IRC Code Compliance Requirements:}

Assumption: 1/2" gypsum thermal barrier in interior (2009 IRC, R316.4), minimum clearance of 6" above grade/exposed earth in areas of "very heavy" termite infestation (2009 IRC R318.4) Information needs: Installation/use instructions (required from product manufacturer), engineering calculations applying the test data to the specific structure (provided by home manufacturer)

Labeling Requirements: Product must be listed and labeled by an approved agency (2009 IRC, R613.4.1)

- ASTM E-84-flame spread and smoke-developed of 75 and 450 or less, respectively (2009 IRC, R316.3) tested at 4"

- NFPA 286 (corner burn test) - if installed thickness exceeds 4-inches test data is required.

- CFR Title 16, Part 460-documentation of thermal performance (R-value) (2009 IRC, N1101.6)

- May be used prescriptively in accordance with 2009 IRC, R613, if testing provided to show conformance to 2009 IRC, R613. Alternately, requires approval as an alternate material (2009 IRC, R104.11)

- $\quad$ ASTM E-72 - increased transverse wall stiffness and/or racking strength requires approval as an alternate material (2009 IRC, R104.11)

\section{Supplemental IRC Code Performance Characteristics:}

- Door and window openings will require conventional lumber framing unless test data is provided to substantiate SIP header/jamb strength without reinforcement requires approval as an alternate material (2009 IRC, R104.11)

- Where connections cannot be designed using the NDS, connections must be approved as an alternate material (2009 IRC, R104.11))

\subsubsection{Stud walls with Structural Insulative Sheathing}

\section{Basic IRC Code Compliance Requirements:}

Assumption: 1/2" gypsum thermal barrier in interior (2009 IRC, R316.4), minimum clearance of 6" above grade/exposed earth in areas of "very heavy" termite infestation (2009 IRC R318.4) Information needs: Installation/use instructions (required from product manufacturer) Labeling Requirements: Product must be listed and labeled by an approved agency (2009 IRC, R316.2)

- ASTM E-84-flame spread and smoke-developed of 75 and 450 or less, respectively (2009 IRC, R316.3) tested at maximum installed thickness

- NFPA 286 (corner burn test) — if installed thickness exceeds 4-inches test data is required at maximum installed thickness 
- ASTM E-330 - wind load resistance must be documented in accordance with ASTM E330 (2009 IRC, 703.1.2) unless the installation conforms with 2009 IRC, R703.11.2

- CFR Title 16, Part 460 - documentation of thermal performance (R-value) (2009 IRC, N1101.6)

\section{Supplemental IRC Code Performance Characteristics:}

- ASTM E-331 - if to be used as a water resistive barrier (2009 IRC, R703.1.1)

- Increased transverse wall stiffness and/or racking strength requires approval as an alternate material (2009 IRC, R104.11)

\subsubsection{Flash and Batt wall construction}

\section{Basic IRC Code Compliance Requirements:}

Assumption: 1/2" gypsum thermal barrier in interior (2009 IRC, R316.4)

Information needs: Installation/use instructions

Labeling Requirements: Product must be listed and labeled by an approved agency (2009 IRC, R316.2)

- ASTM E-84-flame spread and smoke-developed of 75 and 450 or less, respectively (2009 IRC, R316.3) tested at maximum installed thickness

- NFPA 286 (corner burn test) - if installed thickness exceeds 4-inches, test data is required at maximum in-use thickness.

- CFR Title 16, Part 460 - documentation of thermal performance (R-value) (2009 IRC, N1101.6)

\section{Supplemental IRC Code Performance Characteristics:}

- ASTM E-96 (dry-cup method) — if used as a vapor retarder (2009 IRC, R601.3) requires documentation of water vapor transmission characteristics. Because wall studs interrupt the continuity of the vapor retarder (wood studs greater than 1 perm) issues will exist in various jurisdictions, such as the State of Minnesota.

- Increased transverse wall stiffness and/or racking strength requires approval as an alternate material (2009 IRC, R104.11)

\section{Manufacturing and Process Analysis}

This section addresses the production aspects of each of the designs. The scope includes analysis of fabrication, assembly and finishing activities of each option, with the goal of increasing production rates while improving quality, reducing costs and magnifying the benefits of this research.

\subsection{Producibility}

The manufacturing producibility of each option, the process by which the option would be integrated into the manufacturing fabric, was analyzed focusing on the following factors: 
- Safety

Risk of injury when performing the operations, using the equipment and handling the material

- Quality

Likelihood of scrap, rework, delays in the factory and, worst of all, service calls

- Flow

Risk of disrupting continuous production flow

- Cost

Total cost associated with producing the product (space, equipment, supplies and labor).

As a context for considering implementation of the advanced wall systems in the factory environment, a value stream map (VSM) was created for a typical plant (Norris, CMH facility in Bean Station, TN). The VSM is shown below:

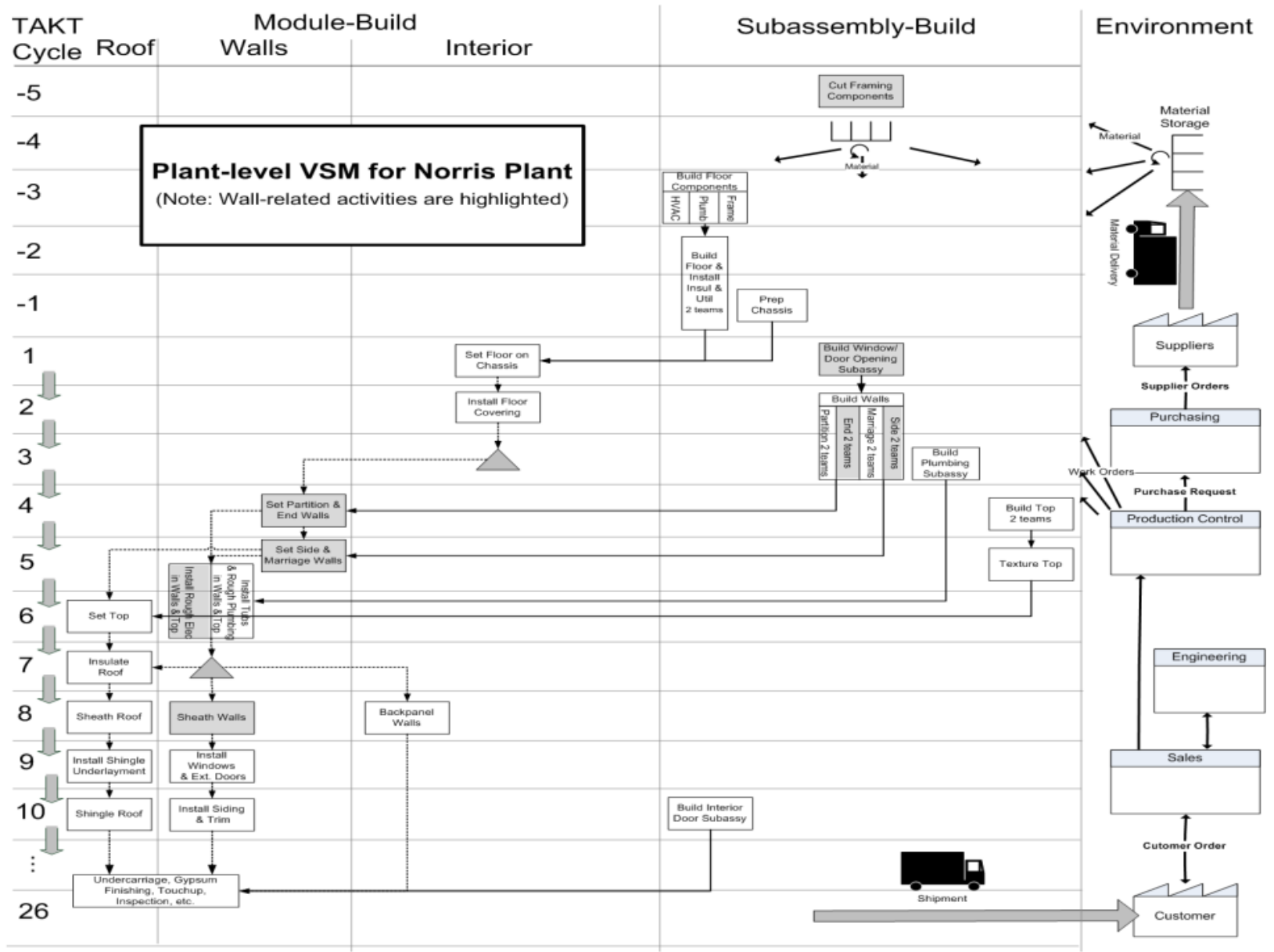

Figure 13. Plant-level value stream mapping for the Norris Plant

\subsubsection{Structural Insulated Panels}

For SIPs, 24' x 8' will be the standard building element size used to build exterior walls. In general, three panels will be used to build each sidewall: two standard size 24 ' $\mathrm{x} 8$ ' panels and 
one shorter panel. A panel layout for the front sidewall of the 'model' home is shown in Figure 14.

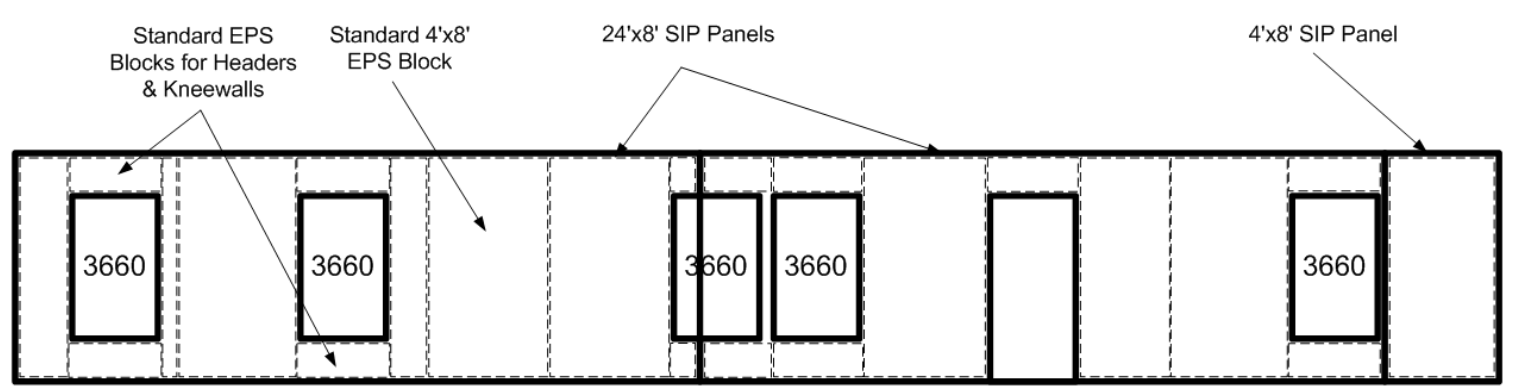

Figure 14. Panel layout for front sidewall of 'model' home

Producibility analysis of the SIP wall construction:

- Safety

- Large components, but safely handled with existing equipment

- Hot wire used to cut foam

- Flow

- SIP production problem can delay line

- Must produce in advance and inspect or maintain inventory of standard SIPs

- Quality

- SIPs must be produced correctly

- Fewer parts and joints reduce risk of errors during wall assembly

- Monolithic structure reduces service problems, such as gypsum board cracking due to loading, shipping, set and settling

- Labor

1.7 hours less than the base case

- Challenges

- SIP production

- Precise EPS and OSB cutting in advance

- Timely layup of SIPs (within "open time")

- Rough wiring

- Aligning electric wall devices on standard vertical chases

- Creating custom vertical chases

- Use of self-contained electrical devices.

\subsubsection{Stud walls with Structural Insulative Sheathing}

The producibility analysis of manufacturing stud walls with structural insulative sheathing follows:

- Safety

Easier to handle 2" x 3" framing components

- Quality

2 " x 3" framing may result in increased service problems such as gypsum board cracking due to shipping, set and settling 
- Flow

Comparable to the base case

- Challenges/opportunities

None

- Labor

0.9 hour more than the base case.

\subsubsection{Flash and Batt wall construction}

Producibility analysis of the flash and batt wall construction follows:

- Safety

- SPF is a hazardous material when spraying. Protective gear required

- Worker spraying SPF must be elevated

- Horizontal application - walking over frame on framing table

- Vertical application - using short step ladder or stool

- Quality

- Demonstrated reduction in service problems such as gypsum board cracking due to loading, shipping, set and settling

- Demonstrated tighter envelope

- Difficult to maintain uniform SPF depth (thermal properties may vary and material wasted)

- Labor

0.6 hour more than the base case

- Flow

- Problems with spray gun, system or materials can disrupt flow. Need spares and possibly inventory of completed walls

- Uneven application can result in spray cycle time variation

\section{- Opportunities}

Optimizing process can save 5.6 labor hours/home

\section{- Challenges}

- Eliminating screws

- Strength of wall system

- SPF cure time before batt installation

- SPF cure time before movement

- SPF creep under frame and bowing gypsum board

- Fastening gypsum board to wider framing. 


\subsection{Comparative Summary of Options}

A comparative study of the marginal labor hours needed to build the options was conducted to evaluate total savings with respect to the base case construction (see Table 8 below).

Table 8. Comparison of Marginal Labor Between Options

\begin{tabular}{|l|c|c|c|c|}
\hline \multirow{2}{*}{ Activity } & \multicolumn{4}{|c}{ Marginal labor per home (labor hours) } \\
\cline { 2 - 5 } & SIP & $\begin{array}{c}\text { Insulative } \\
\text { sheathing }\end{array}$ & $\begin{array}{c}\text { Flash and } \\
\text { batt }\end{array}$ & $\begin{array}{c}\text { Optimized } \\
\text { flash and batt }\end{array}$ \\
\hline Cut wall framing components & -0.4 & 0 & 0 & 0 \\
\hline Build window openings & -0.5 & 0 & 0 & 0 \\
\hline Build exterior walls & -0.7 & -0.5 & 0.6 & -3 \\
\hline Set exterior walls & 0.5 & 0 & 0 & 0 \\
\hline Rough wiring & 0.8 & 0 & 0 & 0 \\
\hline Sheathing & -1.4 & 1.4 & 0 & 0 \\
\hline Other & 0 & 0 & 0 & -2 \\
\hline Total savings & $\mathbf{- 1 . 7}$ & $\mathbf{0 . 9}$ & $\mathbf{0 . 6}$ & $\mathbf{- 5}$ \\
\hline
\end{tabular}

A qualitative analysis of the proposed options was conducted to evaluate the ease of manufacturability of each option. Scoring was based on the producibility factors, embodied labor content and plant space requirements. Grades were assigned between A through D, with A being the best performance and $\mathrm{D}$ the worst. Grade $\mathrm{C}$ is equivalent to base case performance. Individual attributes were summed up to an overall production grade for the wall strategy.

Table 9. Production Grades

\begin{tabular}{l|r|r|r|c}
\hline Quality & SIP & $\begin{array}{c}\text { Insulative } \\
\text { sheathing }\end{array}$ & $\begin{array}{c}\text { Flash and } \\
\text { batt }\end{array}$ & $\begin{array}{c}\text { Optimized } \\
\text { flash and batt }\end{array}$ \\
\hline Safety & B & C & D & D \\
\hline Quality & A & C & B & A \\
\hline Flow & D & C & D & D \\
\hline $\begin{array}{l}\text { Challenges and } \\
\text { opportunities }\end{array}$ & D & C & C & C \\
\hline Labor ( \pm hr/home) & -2 & 1 & 1 & -5 \\
\hline Space needed (sq. ft.) & 3,000 & 0 & 150 & 150 \\
\hline Overall grade & C+ & C & C & C+ \\
\hline
\end{tabular}

Note: "C" equivalent to base case 


\section{Cost of Implementation}

Overall costs associated with the production, fabrication and assembly of the proposed wall strategies were compared against base case construction.

\section{Approach}

The general parameters for comparing the cost of implementation are as follows:

- Incremental cost analysis

- Plant capacity: 1,000 homes (2,000 floors)

- Capital recovery period (yr): 10

- Rate of return: $20 \%$

- Manufacturing area (sq. ft.): 2,500.

The following table analyzes the incremental fixed costs associated with the three options when compared to the base case.

Table 10. Comparison of Fixed Costs of Options

\begin{tabular}{|c|c|c|c|c|c|c|c|}
\hline \multirow{2}{*}{ Construction } & \multirow{2}{*}{$\begin{array}{l}\text { Capital } \\
\text { costs }(\$)\end{array}$} & \multirow{2}{*}{$\begin{array}{c}\text { Annualized } \\
\text { capital costs } \\
\text { (\$/year) }\end{array}$} & \multirow{2}{*}{$\begin{array}{c}\text { Fixed } \\
\text { operating } \\
\text { costs }(\$ / \text { year })\end{array}$} & \multirow{2}{*}{$\begin{array}{c}\text { Total } \\
\text { (\$/year) }\end{array}$} & \multicolumn{3}{|c|}{$\begin{array}{l}\text { Production related } \\
\text { costs }(\$ / \text { home })\end{array}$} \\
\hline & & & & & 300 & 650 & 1,000 \\
\hline $\begin{array}{l}\text { Structural insulated } \\
\text { panels }\end{array}$ & $\$ 560,000$ & $\$ 133,573$ & $\$ 130,240$ & $\$ 263,813$ & $\$ 879$ & $\$ 406$ & $\$ 264$ \\
\hline $\begin{array}{l}\text { Structural insulative } \\
\text { sheathing }\end{array}$ & $\$ 14,915$ & $\$ 3,558$ & $\$ 0$ & $\$ 3,558$ & $\$ 12$ & $\$ 5$ & $\$ 4$ \\
\hline Flash and batt & $\$ 54,864$ & $\$ 13,086$ & $\$ 10,022$ & $\$ 23,108$ & $\$ 77$ & $\$ 36$ & $\$ 23$ \\
\hline
\end{tabular}

Table 11 shows the combined costs (fixed and variable) amortized over various production volumes.

Table 11. Marginal Costs by Production Volume (\$/sq. ft. of net wall area)

\begin{tabular}{|c|c|c|c|c|c|c|c|c|c|}
\hline \multirow{3}{*}{ Cost component } & \multicolumn{9}{|c|}{ Production volume } \\
\hline & \multicolumn{3}{|c|}{300} & \multicolumn{3}{|c|}{650} & \multicolumn{3}{|c|}{1,000} \\
\hline & SIPs & IS & F\&B & SIPs & IS & F\&B & SIPs & IS & F\&B \\
\hline Material costs (\$/sq. ft.) & $\$ 0.70$ & $\$ 0.14$ & $\$ 0.42$ & $\$ 0.70$ & $\$ 0.14$ & $\$ 0.42$ & $\$ 0.70$ & $\$ 0.14$ & $\$ 0.42$ \\
\hline Direct labor (\$/sq. ft.) & $-\$ 0.03$ & $\$ 0.02$ & $\$ 0.01$ & $-\$ 0.03$ & $\$ 0.02$ & $\$ 0.01$ & $-\$ 0.03$ & $\$ 0.02$ & $\$ 0.01$ \\
\hline Fixed costs (\$/sq. ft.) & $\$ 0.80$ & $\$ 0.01$ & $\$ 0.07$ & $\$ 0.37$ & $\$ 0.00$ & $\$ 0.03$ & $\$ 0.24$ & $\$ 0.00$ & $\$ 0.02$ \\
\hline Testing costs ( $\$ /$ sq. ft.) & $\$ 0.00$ & $\$ 0.00$ & $\$ 0.00$ & $\$ 0.00$ & $\$ 0.00$ & $\$ 0.00$ & $\$ 0.00$ & $\$ 0.00$ & $\$ 0.00$ \\
\hline Total & $\$ 1.47$ & $\$ 0.17$ & $\$ 0.50$ & $\$ 1.04$ & $\$ 0.16$ & $\$ 0.46$ & $\$ 0.91$ & $\$ 0.16$ & $\$ 0.45$ \\
\hline
\end{tabular}




\section{Next Steps}

Phase 2 findings were presented at the Expert Meeting for evaluation and assessment of the viability of each of the options to move further to Phase 3: Full-scale implementation and testing. The selection of the viable option(s), those with the potential to be embraced by industry, will be made by the project industry committee in the near future. The Committee will consider the information presented above including any "fatal flaws" that would eliminate the option from further consideration.

Phase 3, to be conducted during 2012, will conclude the research and will include two major efforts. The first will demonstrate the manufacturing plan in a participating partner plant. This full-scale implementation will help refine the production process and plant flow. The second part of Phase 3 will complete the testing using full-scale mock ups of homes built in the partner facility and incorporating one or more of the high performance wall technologies into typical plant operations.

\section{Research Activity Gaps and Barriers}

Following are research questions that will need to be addressed as the work proceeds:

1. Who is responsible for carrying out the necessary testing for a technology to be deemed structurally sound?

2. What is the impact of the technology on the build of the other components?

3. Are there any deal-killers associated with any technology(ies) - qualities that would preclude its use, aspects that can't be addressed through research? Qualities such as: high cost, market acceptance, significant retooling and staff training challenges, insurmountable technical hurdles, etc.

4. What markets are most appropriate for the technology? For example: manufactured homes or modular homes, low end to high end, cold, temperate or hot climates, spot markets demanding superior energy performance (e.g., California). 


\section{U.S. DEPARTMENT OF Energy Efficiency \& ENERY Renewable Energy}

